Љиљана Рогач Мијатовић

Универзитет уметности

Београд

Факултет драмских уметности
316.722

https://doi.org/10.18485/climb.2017.5.1.ch10

\title{
ХУМАНИСТИКА У ПЕРСПЕКТИВИ НАУЧНЕ ИЗВРСНОСТИ И ЕВРОПСКИХ ИСТРАЖИВАЧКИХ ПОЛИТИКА ${ }^{1}$
}

\section{Садржај}

Хуманистика се данас налази пред изазовима вредновања резултата научноистраживачког рада, па и потврде своје релевантности и друштвеног значаја. У раду се полази од сложених глобалних токова и промењених образаца управљања у високом образовању, у којима се артикулишу захтеви за хуманистику иманентни логици природних и техничких наука. Намера рада је да критички испита концептуалне и методолошке претпоставке критеријума евалуације и индикатора изврсности за хуманистику у оквиру савремених европских истраживачких политика, те њихове импликације на рад истраживача и сама исходишта сазнања.

Кључне речи: хуманистичке науке, научна изврсност, епистемологија, истраживачке политике, високо образовање, интердисциплинарност, ЕУ, Србија

У глобалном окружењу које се убрзано мења у сенци дигиталне револуције, на делу је „растакање“ традиционалних поредака организације знања као део трансформација „когнитивног капитализма“" (Fumagalli 2010). Глобализација и неолиберализам постали су доминантни фактори у обликовању праваца друштвеног развоја, као и у процесима стварања специфичних облика знања на почетку XXI века, посебно у преображајима научне културе која идеју познавања

1 Рад је делом настао као резултат рада на пројекту бр. 178012 Факултета драмских уметности који финансира Минстарство просвете, науке и технолошког развоја. 
света све више заснива на парадигми нових технологија, односно „дигиталном обрту“. Криза у којој су се хуманистика и уметности нашле коинцидира са светском кризом образовања и кризом демократије, па су у општој трци за економским растом и профитом у јавним политикама ове дисциплине све више перципиране као неефикасне и у крајњем исходу бескорисне (Nusbaum 2012). Хуманистичке дисциплине суочене су, коначно, са кризом темеља у производњи знања, спрам новог састава како научне културе тако и саме хуманистичке културе (Рогач Мијатовић 2015).

Дилеме о будућности хуманистике односе се и на покушаје изградње односа између природних и хуманистичких наука на новим темељима, изван парадигме о „две културе“ (С. P. Snow). Испитујући карактеристике које хуманистичке науке деле са природним и друштвеним наукама, као и оно што их разликује од других научних области, дански теоретичар Хојруп (Jens Höyrup) оцењује да су значај и вредност хуманистичких наука у томе што кореспондирају са немачким Wissenschaft, односно латинским scientia - као систематски организовани корпус знања, а не као област знања која би требало да симулира квантитативне и експерименталне приступе природних наука (у ужем смислу енглеског science) (Hoyrup 2000: 12). Неспорно је, дакле, да теоријско истраживање и практична активност треба да буду узајамно поткрепљујући, обједињени принципом „знање као чињење“.

Како позиционирати хуманистику у ширим оквирима савремене научне мисли и јавног деловања, како би се омогућио њен опстанак у сложеном (и претећем) окружењу? Каква је природа истраживачких пракси у хуманистци у светлу институционализације и професионализације у економији знања? Каква је улога савремених универзитета у развоју истраживања у хуманистици? И шта се данас очекује од наставника и истраживача у том погледу?

У циљу промишљања промена у организацији академског и истраживачког рада на универзитетима, као и трансформације у политикама високог образовања и научно-истраживачког рада, неопходна је мултиперспективна анализа повезаности знања, вредности, ауторитета и моћи, те начина на који се они огледају у институционалним структурама и праксама.

Одбрана академског мишљења и исходишта сазнања, односно истраживачког интегритета у хуманистици представља суштински из- 
Култура и/или наука

азов у погледу нове динамике истраживачких политика у Европи и широм света. Опстанак хуманистичких наука као истраживачких области постао је посебно значајна тема у светлу нормативних критеријума за вредновање научно-истраживачких резултата, односно критеријума који дефинишу научну изврсност. Маргинализација остварења и доприноса хуманистичких наука део је процеса „ерозије“ друштвеног значаја и релевантности хуманистике (Ferrini 2015: 44). Овај проблем наслања се на општи оквир јавних политика у области научних истраживања и развоја као и менаџмента универзитета.

Академик Владимир Костић истиче да је у контексту глобализације и образовања универзитет кључно место синтезе образовних и истраживачких пракси, а да нове парадигме производње знања карактеришу значај тог контекста и то кроз редефинисање релевантног, употребљивог знања (Костић 2015: 182).

У новијим концепцијама знања и образовања, условљених глобализацијом и новим технологијама, наука је виђена као инструмент решавања проблема и као облик инвестиције, као део ширих токова комодификације и маркетизације знања. Осврћући се на перспективе друштвених и хуманистичких наука пред изазовима постдисциплинарности и тржишта, Александра Павићевић указује на то да,

промена концепта знања није последица само ослобађања од научних догми нити од ширења граница дисциплина, већ да се она одвијала и под латентним утицајима процеса свеобухватне меркантилизације, у складу са новим, глобалним економско-политичким идеологијама. У вези са овим опажањем свакако могу бити одјеци у научном свету културе ревизије (audit culture), која намеће императиве тржишта у областима које доскора нису биле, а ни сада нису превише конкуретне ни на тржишту новоконципираног знања ни на тржишту робе. (Павићевић 2013: 10) Управни одбори државних универзитета широм Европе већ усмеравају факултете у пољу хуманистичких наука ка следећим приоритетима: редефинисање деловања ка „употребљивом знању“ и прилагођавање научно-истраживачког рада националном систему евалуације; јачање видљивости заснованог на научним резултатима и позиционирање на глобалном тржишту високог образовања као и међународном (и/или регионалном) тржишту рада, као и 
умрежавања и сарадње са универзитетима ради побољшања видљивости и утицаја у својој области експертизе. Универзитети из Западне Европе и САД (али и Индија и Кина) имају водећу улогу у светском рангирању универзитета будући да су стратешки инвестирали у развој високог образовања у циљу економског раста. Иако постоје аутори који доводе у питање поузданост рангирања, оно постало је моћан нормативни инструмент за изврсност (excellence) како за рад администрације на универзитетима, тако и за резултате рада професора и студената.

Нови систем за процену квалитета истраживања високошколских установа у Великој Британији под називом Оквир за истраживачку изврсност (The Research Excellence Framework - REF) међу индикаторима утицајности научних истраживања (research impact) препознаје чак 36 индикатора који се односе на стварање нових бизниса, комерцијализације нових производа или процеса, као и привлачења инвестиција, док се само један индикатор посредно односи на хуманистику, у смислу успостављања бољег квалитета живота.

Један у низу елемената овог преокрета у вредновању научноистраживачких резултата је и продукција научних радова у високорангираним врстама научних публикација, и истовремено запостављање објављивања у нижерангираним публикацијама, као што су зборници радова, или локални научни часописи. Стандард за академску односно научну изврсност постао је високоспецијализовани чланак у међународном часопису који излази на енглеском језику са високим импакт фактором. Ова врста критеријума вредновања резултата иду у правцу хиперспецијализације и јачања фрагментарних оквира референтности. На тај начин се, парадоксално, у одређеној мери онемогућује испуњење критеријума „примењивости“ истраживања, њиховог друштвеног значаја, као релевантности за друга научна поља.

Вредновање научно-истраживачких резултата и метрика за квалитет научних истраживања постали су контроверзна тема, којом су и истраживачи и универзитети / институти, као и сами научно-истраживачки пројекти увучени у својеврстан евалуацијски perpetuum mobile. Квантификација научно-истраживачких резултата углавном се спроводи кроз индексе цитатности и академске ранг листе. Многи документи се баве могућим злупотребама ових рангирања и успостављају критеријуме за организацију евалуације. Декларација ДОРА (DORA Declaration) усвојена је са намером да се заустави пракса 
којом се ставља у корелацију импакт фактор часописа у вредновању научно-истраживачког доприноса истраживача. Препознајући потребу за побољшањем начина за вредновање научног истраживања, у декларацији се истиче да су резултати тог рада бројни и разноврсни, укључујући истраживачке текстове у којима се указује на нова (са) знања и податке, интелектуалну својину, и високообразоване младе научнике, те да стога императив треба да буде прецизно мерење и мудра процена резултата рада и научно-истраживачког доприноса.

Постоје реалне основе за забринутост у погледу повезаности финансирања научно-истраживачког рада са самим резултатима, јер се истраживачки резултати често вреднују само у погледу имена издавача, броја цитата, утицајности научног часописа, итд. Импакт фактори и цитатне базе података иза којих стоје глобалне издавачке компаније (као што су Web of Science Thompson Reuters, Scopus Elsevier) постали су окосница индустрије научно-истраживачке и издавачке делатности према којима се постављају нормативни поретци за научну изврсност. ${ }^{2}$ Међу негативним последичним појавама истичу се предаторски часописи, који додатно отежавају напоре истраживача за објављивањем резултата научно-истраживачког рада у складу да постављеним правилима.

Још један у низу аргумената о тешко савладивим изазовима и неповољној слици о учинку истраживачких резултата у хуманистици јесте чињеница да истраживачи који делују изван англосаксонског говорног подручја и који не објављују на енглеском језику имају знатно мање шансе за достизање поменутих параметара научне изврсности. Теме којима се ови истраживачи баве (нпр. језик, национална историја, културни идентитет, културна баштина, и сл.) спадају у корпус тзв. националних наука и неретко су од значаја превасходно (али не и једино) за домаћу академску заједницу. ${ }^{3}$ Таква ситуација присут-

2 Један од индикативних примера је ЕРИХ плус листа (European Reference Index for the Humanities) која има циљ да појача глобалну видљивост висококвалитетних истраживања у друштвено-хуманистичким наукама широм Европе. У критеријумима за укључење нових научних часописа на листу дефинисано је да научни часописи са локалним ауторима (из једне институције) не могу ући на листу, већ само они са националним (и то да су две трећине аутора из исте земље али не и исте институције) и међународним.

3 За евалуацију научно-истраживачких резултата у хуманистичким наукама у Србији, посебно објављивања у међународним часописима и библиометријских индикатора, то јест научног учинка у међународним часописима погледати, Шипка 2016: 309-329. 
на је, међутим, не само у мањим земљама, већ и у многим развијеним западноевропским земљама које предњаче у примени већ поменутих критеријума евалуације и научне изврсности.

У средишту савремених европских истраживачких политика које су усмерене на стварање и обликовање параметара новог знања заснованог на изврсности је отворена наука (open science). Реч је о моделу научних политика заснованих на доказима (evidence based science policy) као делу јавне политике (public policy) ЕУ у овој области, под називом Одговорно истраживање и иновације (Responsible research \& innovation). Главна амбиција отворене науке јесте у томе да понуди темељније вредновање традиционалних научних публикација, препознајући уз то разноврсност научних резултата у новим формама. Отворена наука тиче се тема и питања инфраструктуре, политике, података, индикатора и мерења, а фокус је управо на изврсности односно квалитету. ${ }^{4}$ Ове политике се у техничком односно апликативном смислу односе на успостављање принципа отвореног приступа, то јест отварања целокупног система публиковања научно-истраживачких резултата и стварање окружења за интерактивну комуникацију. Отворени приступ научним информацијама подразумева право сваког корисника интернета да без финансијских издатака чита, преузима, чува, штампа и користи дигитални садржај, са једином обавезом да коректно наведе извор информација. Друга кључна тема у том контексту је План меначмента истраживачких података (Research Data Management Plan) којим се предвиђа прелазак са научних публикација као јединице мерења на саме податке, што обухвата низ тема и нових захтева, попут нове регулативе на пољу ауторских права, заштите података, слободог протока података, итд.

У заједничком стратешком оквиру за нови циклус финансирања 2014-2020 ЕУ Истраживање и иновације по први пут су истакнуте друштвено-хуманистичке науке и то у смислу јачања истраживања о инклузивним, иновативним и рефлексивним друштвима, као и у правцу истраживања и заштите европског културног наслеђа. Оквирни програм Наука са друштвом и за друштво (Science with and for Society) у чијој је окосници повезивање науке са друштвом у циљу изграде сарадње, садржи управо кључне принципе европских истра-

4 Више о овој теми погледати у: European Open Science Cloud 2017. 
Култура и/или наука

живачких политика, а то су: одговорно истраживање и иновације; отворена наука и отворени приступ; родна једнакост, етика и научна едукација. Изврсност у науци (excellence in science) главни је стуб оквирног програма за истраживање и иновације Хоризонт 2020 који од 2014. године развија и финансира ЕУ. За све радове односно пројекте који се финансирају кроз овај оквирни програм објављивање резултата у отвореном приступу је обавеза и услов одрживости пројекта. ${ }^{5}$

Вредновање научно-истраживачког рада засновано на принципима изврсности, као и сам концепт „изврсности“ постали су предмет критике у многим академским заједницама, чиме се показују сложености, дилеме и контроверзе у вези са европским и глобалним научно-истраживачким политикама. Критички преиспитујући нормативне оквире истраживачког рада на универзитетима које прожима реторика „изврсности“, група аутора указује на непостојање „унутрашњег смисла" овог концепта изван наратива компетитивности односно његове употребе као инструмента организације, финансирања и награђивања науке и научно-истраживачког рада (Moore et al. 2017). Изврсност као „свети грал академског живота“ дефинише се на различите начине и од стране различитих актера, а посматра се често кроз процес рецензирања и вредновања истраживачких резултата (Lamont 2009: 1). Критика дискурса изврсности управо је усмерена на непостојање темељне „културе вредновања“ као општеприхваћеног оквира „заједничких стандарда“.

Појам изврсност суштински је празан концепт, што значи да нема природну референтну тачку и никакав нарочит идеолошки садржај. Разумевање изврсности иде изван повезаног значења квалитета, будући да је она инхерентно релациона [...] То чини концепт изврсности корисним као политичко средство, али захтева праксе и процедуре које га могу испунити садржајем [...] Као референце на изврсност, рангирања формулишу и помажу институционализовање мера и пракси достизања успеха, као кохерентну глобалну дефиницију академског квалитета. (Wedlin 2014:71)

Примат овакве техно-научне логике представља структурну аномалију у оквиру доминантне парадигме модерне рационалности

5 Више о учешћу Србије у овом оквирном пргораму, Србија у програму Хоризонт 2017. 
и указује на неопходност другачијег мишљења у виду хуманистичке културе и новог хуманизма (Bianco 2016).

Међународне организације попут УНЕСКО-а уврстиле су на своју агенду питање опстанка и будућности хуманистике. Бусанска декларација: ка новом хуманизму за 21. век која је усвојена под окриљем УНЕСКО-а 2011. године у оквиру Светског форума хуманистике, кроз сет препорука указује на хитност решавања тренутног статуса хуманистичких наука и промишљања значења хуманизма, у смислу:

- Немерљивог доприноса хуманистике у критичком промишљању о људским вредностима и друштвима, као и у обнови вредности у времену глобализације, међузависности и успону неизвесности;

- Потребе за обновљеним хуманизмом [...] кроз строгу анализу, дијалог и сарадњу између истраживача у хуманистици, уметника, интелектуалаца и иноватора различитих оријентација и профила;

- Промоције и подршке принципима плуралистичке, инклузивне и отворене мисли и националних, језичких и културних граница широм дисциплина, у сарадњи са друштвеним и природним наукама, са приступом који појачава могућности система истраживања, и омогућује медијима и друштву да разумеју своју садашњост и осмисле своју будућност;

- Равнотеже између неопходног поштовања за разноликост и заједничке вредности без којих друштва не могу да живе у миру и просперитету, и свету који треба да успостави обновљену хуманистичку основу за универзалне вредности;

- Успостављања веза између хуманистике и друштвених и природних наука у правцу јачања капацитета савремених друштава за суочавање са актуелним и будућим изазовима;

- Јачања утицаја хуманистике кроз успостављање нових мрежа и јачање постојећих на националном и регионалном нивоу у правцу повезивања истраживача у хуманистици, креатора јавних политика, професионалаца и медија. (UNESCO 2011)

На трагу ове декларације, усвојен је још један документ - Агенда Нове хуманистике за 21. век, под окриљем УНЕСКО-а и MOST програма, као подршка глобалној Агенди за одрживи развој 2030, са циљем признавања специфичности приступа и компетенција хуманистике, којом су обухваћене области филозофије, историје, 
Култура и/или наука

књижевности и језика, као и уметности. Ова агенда конкретизује захтеве који се постављају пред релевантне међународне организације, асоцијације, државне и приватне институције које учествују у процесу финансирања и креирања јавних политика, кроз:

успостављање транспарентних механизама финансирања за хуманистику, обезбеђујући академску независност истраживача и ширу дисеминацију знања које проистиче из тих напора; успостављање механизама у свакој земљи за синтетизовање резултата из хуманистичких наука и њихово представљање креаторима јавних политика и представницима цивилног друштва. (A New Humanities Agenda for the 21st Century 2017)

Овим документом упућује се и апел високошколским институцијама, академијама, иститутима и академској заједници за препознавање специфичних и транспарентних критеријума за квалитативна истраживања у хуманистици, за неговање језичке разноликости у академским публикацијама, као и плурализма у производњи знања уопште.

Као што је указано, позиционирање хуманистике и њен учинак у савременом пределу научно-истраживачких политика у значајној мери одређени су критеријумима који потичу и одговарају превасходно логици других научних дисциплина, као и вредносним обрасцима „изврсности“ који последично воде ка хипер-компетитивности. То води на коначном питању: Шта чинити? Пред истраживаче се поставља изазов развијања алтернативних наратива „изврсности“ и параметара квалитета научно-истраживачког рада, односно целокупне научне културе на којој почивају истраживања у хуманистици. Потребно је расплести мрежу (дискурс) изврсности на начин који ће омогућити опстанак хуманистичке традиције и културе, истовремено се укључујући и усклађујући са новим токовима.

Кроз мултиперспективни приступ, на трагу критичке анализе, могуће је упутити више предлога за изврсност и одрживост научних истраживања у хуманистици, који су окупљени око следећих принципа:

- Хуманистика као јавно добро;

- Интегритет истраживања односно истраживача;

- Интердисциплинарност као окосница нове хуманистике;

- Квалитативни односно „културни извори“ као кључ разумевања доприноса хуманистичких наука савременом друштву; 
- Обогаћивање пракси вредновања истраживања кроз нове критеријуме који ће успоставити баланс између квалитативних и квантитативних параметара;

- Креативне трансформације кроз комбинације старог и новог знања, изградња „средњег пута“ између науке и културе, као пут за „превођење“ знања у праксу.

Коначно, ми истраживачи, показујући доследност у погледу веродостојности истраживања и одлучност у изградњи снажне научне културе и заједнице, позвани смо да градимо изврсност у хуманистици на новим темељима, негујући традицију квалитативних истраживања и приступа.

\section{Извори и литература}

A New Humanities Agenda for the 21st Century 2017. Web. 20.01.18. http://www.humanities2017.org/en/content/new-humanities-agenda-21st-century

Bianco, Gabriella. "The Humanities and the Humanism of the Future: Need of Sense, New Anthropology and New Ethics", El Pensamiento Latinoamericano, CECIES, 2016. Web. 20.01.18. http://www.cecies.org/articulo.asp?id=604

European Open Science Cloud 2017. Web. 20.01.18. https://ec.europa.eu/research/ openscience/index.cfm?pg=open-science-cloud

Ferrini, Cinizia. "Research 'Values' in the Humanities: Funding Policies, Evaluation, and Cultural Resources. Some Introductory Remarks" Humanities Vol. 4, 2015. pp. 4267. Web. 15.01.2017.

Fumagalli, Andrea. Cognitive Capitalism and Its Reflections in South-Eastern Europe, Peter Lang, 2010. Print.

Hoyrup, Jens. Human Sciences: Reappraising the Humanities Through History and Philosophy, 2000, SUNY Press, print.

Костић, С. Владимир. „Глобализација и образовање“. Александар Костић (ур.) Образовање: развојни потенцијал Србије. Београд: Српска академија наука и уметности, 2015. стр. 177-190. Штампано.

Lamont, Michele. How Professors Think: Inside the Curious World of Academic Judgement. Cambridge, Mass: Harvard University Press, 2009. Print.

Moore, Samuel, Cameron Neylon, Martin Paul Eve, Daniel Paul O'Donnell \& Damian Pattinson. "Excellence R Us: university research and the fetishisation of excellence", Palgrave Communications Volume 3, Article number: 16105, 2017. Web. 15.01.2018. www.nature.com/articles/palcomms2016105

Nusbaum, Marta. "Ne za profit: Zašto je demokratiji potrebna humanistika?" Reč br. 82, Beograd: Fabrika knjiga, 2012. Veb. 15.04.2017. (Original: Martha C. Nussbaum, Not for Profit. Why Democracy Needs the Humanities. Princeton N. J.: Princeton 
Култура и/или наука

University Press, 2010; "The Silent Crisis", str. 1-11; "Education for Profit, Education for Democracy", str. 13-26.)

Павићевић, Александра. „Друштвене и хуманистичке науке пред изазовима постдисциплинарности и тржишта. Искуства у вези са осмишљавањем, организовањем и финансирањем научних истраживања" Гласник Етнографрског института САНУ . Књ. 61, Св. 2 (2013), стр. 9-12. Штампано.

Research Excellence Framework 2021. Web. 17.05.2017. http://www.ref.ac.uk/

Responsible research \& innovation https://ec.europa.eu/programmes/horizon2020/en/ h2020-section/responsible-research-innovation Web. 17.05.2017.

Србија у програму Хоризонт http://horizon2020.mpn.gov.rs/ Web. 17.05.2017.

The San Francisco Declaration on Research Assessment (DORA) 2013. Web. 17.05.2017. http://www.ascb.org/dora/

UNESCO, Busan Declaration. Towards a New Humanism for the 21st Century. 2011. Web. 20.01.18. http://unesdoc.unesco.org/images/0022/002212/221283e.pdf

Шипка,Перо. „Интернационализацијаи евалуација као изазовисрпскехуманистике“. Александар Костић (ур.) Наука: стање, стратегија, перспективе. Београд : Српска академија наука и уметности, 2016. стр. 309-329. Штампано.

Wedlin, Linda. "How global comparisons matter: The 'truth' of international rankings" in Bibliometrics. Use and Abuse in the Review of Research Performance. London: Portland Press, 2014, pp. 65-75. Print.

\section{Ljiljana Rogač Mijatović}

University of Arts in Belgrade

Faculty of Dramatic Arts

\section{THE HUMANITIES IN THE PERSPECTIVE OF SCIENTIFIC EXCELLENCE AND EUROPEAN RESEARCH POLICIES}

\section{Summary}

The humanities of today are facing demanding challenges of assessing the results of scientific research, social impact, as well as justification of their own relevance and achievements. The survival of the humanities as a field of research has become a particularly important topic in the light of normative criteria for the evaluation of scientific research results, or the criteria that define scientific excellence. This paper 
takes as the starting point the complex political and economic context in which the demands that are placed in front of the humanities are articulated, and which are largely immanent to the logic of natural and technical sciences. The paper intends to investigate the methodological assumptions and conceptual implications against the evaluation criteria and indicators of excellence for the humanities within the current European research policies. Of particular importance is the argument that the establishment of technical and methodological knowledge production orders, as well as the imperative of excellence, puts influence to both the value foundations of the humanities, as well as to the overall outcomes of knowledge. EU framework programmes are taken as an indicative example for understanding complexity, controversies and dilemmas of the issue through assessment of critical analysis and research practices. In this light, the paper raises questions: What is the future of the humanities in the perspective of European research policy? What could the humanities offer to the major social challenges at times of technological domination? Defending academic thinking and learning outcomes, and research integrity in the humanities is an essential challenge of the new dynamics of research policies in Europe and around the world. Through a multi-perspective approach, along the lines of critical analysis, it is possible to make several proposals for the excellence and sustainability of scientific research in the humanities, which are clustered around the following principles: Humanities as a public good; The integrity of research and research; Interdisciplinary as the backbone of the new humanities; Qualitative and "cultural resources" as a key to understanding the contribution of humanities to the contemporary society; Enrichment of research evaluation practices through the new criteria to establish a balance between qualitative and quantitative parameters; Creative transformation through a combination of old and new knowledge, building a "middle way" between science and culture, as a way of knowledge "translation" into practice. 